\title{
Estimating Leaching Requirements for Barley Growth under Saline Irrigation
}

\author{
Ahmed Al-Busaidi ${ }^{*}$, Jaaman Rabeea ${ }^{2}$, Mushtaque Ahmed ${ }^{1}$, \\ and Salim Al-Rawahy ${ }^{1}$ \\ ${ }^{1}$ College of Agricultural \& Marine Sciences, Sultan Qaboos University, \\ P.O. Box 34, Al-Khod 123, Sultanate of Oman \\ ${ }^{2}$ Directorate General of Agriculture \& Livestock Research, Rumais, \\ Ministry of Agriculture, Sultanate of Oman
}

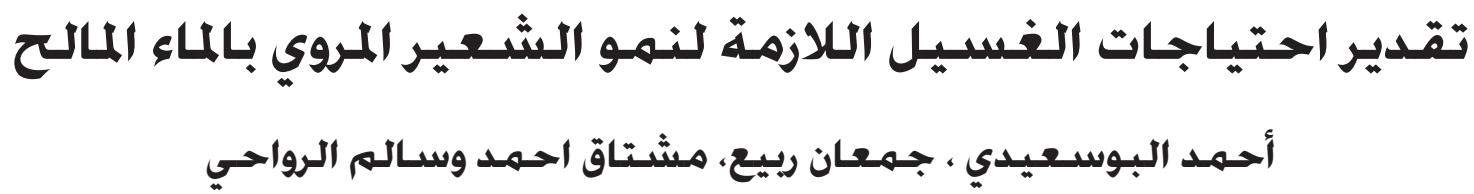

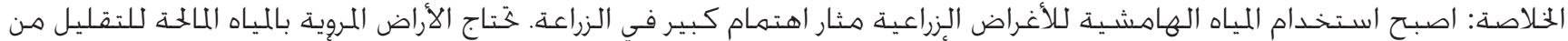

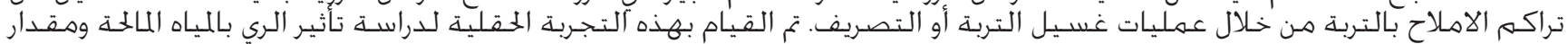

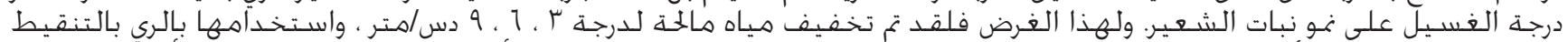

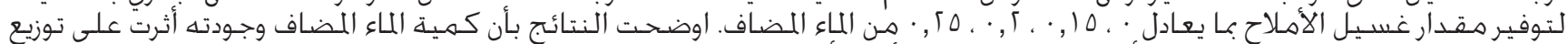

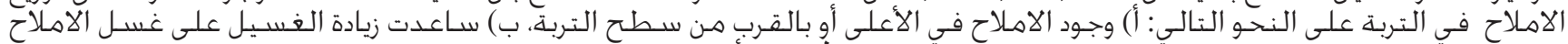

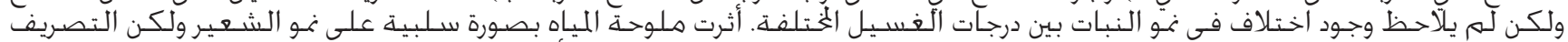

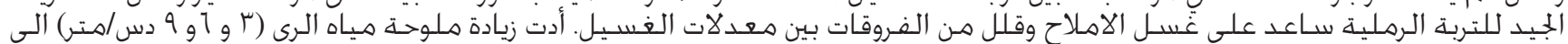

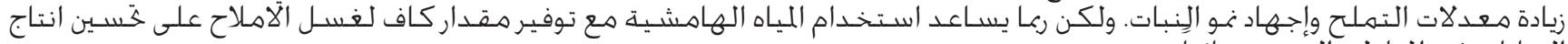

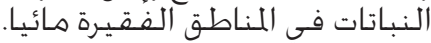

$$
\text { كلمات مفتاحية: تراكم الامـلاح ، التوصيل الكهربائي ، الري بالتنقيط }
$$

ABSTRACT: The utilization of marginal water resources for agriculture is receiving considerable attention. The lands irrigated with saline water are required to reduce salt accumulations through leaching and/or drainage practices. A field experiment was carried out to investigate the effect of saline irrigation and leaching fraction on barley (Hordeum vulgare L.) growth. For this purpose highly saline water was diluted to the salinity levels of 3,6 and $9 \mathrm{dS} \mathrm{m}^{-1}$ and applied by drip irrigation at 0.0, 0.15, 0.20 and 0.25 leaching fractions (LF). The results of the experiment showed that both quantity and quality of water regulated salts distribution within the soil in the following manner: a) the salts were found higher near or immediate below the soil surface; b) an enhanced LF carried more salts down the soil horizon but there was no significant difference in plant yield between different treatments of leaching fractions. Salinity of water significantly impaired barley growth. The good drainage of sandy soil enhanced the leaching process and minimized the differences between leaching fractions. The increment in saline treatments $\left(3,6\right.$ and $\left.9 \mathrm{dS} \mathrm{m}^{-1}\right)$ added more salts and stressed plant growth. However, the conjunctive use of marginal water at proportional LF could be effective in enhancing the yield potential of crops in water-scarce areas.

Keywords: Salt accumulation, electrical conductivity (EC), drip irrigation.

\section{Introduction}

The freshwater resources available for agriculture are declining quantitatively and qualitatively. The water demands for irrigation are projected to rise, bringing increased competition between agriculture and other users. Therefore, the use of lower-quality supplies will inevitably be practiced for irrigation purposes to maintain an economically viable agriculture(Oron et al., 2002). Scarcity of good quality water in several regions in the world emphasizes the need to use marginal waters such as brackish water or reclaimed effluent to meet the increasing demands for water, which in turn increases the possibility of soil salinization and yield reduction (Chartzoulakis et al., 2001). Poor management of saline water may increase the soil salinity to a level higher than crop tolerance. Therefore, the challenge is to manage poor quality water and salinized soil for sustainable agricultural production system. The soils irrigated with saline water are required to reduce salts accumulations through leaching and/or drainage practices. The amount of excess water that is applied to the crop in order to control salts is referred as the leaching fraction. In regions where the rainfall is low, a higher water fraction is added to irrigation water as drainage to lower the salt accumulation in the soil (NATO, 1994). Oron et al. (2002) reported that high saline water has an agricultural potential if conducted through proper irrigation management. By increasing the volume of irrigation water, the soil salinity may be reduced due to water percolation below the root zone (Petersen, 1996). 
Table 1. Selected physicochemical characteristics of soil.

\begin{tabular}{ll}
\hline Property & Value \\
\hline $\mathrm{EC}_{\mathrm{e}}$ & $3.06 \mathrm{dS} \mathrm{m}^{-1}$ \\
$\mathrm{Ph}$ & 8.31 \\
Soluble $\mathrm{K}^{+}$ & $7.00 \mathrm{mg} \mathrm{kg}^{-1}$ \\
Soluble $\mathrm{Ca}^{2+}$ & $48.70 \mathrm{mg} \mathrm{kg}^{-1}$ \\
Soluble $\mathrm{Mg}^{2+}$ & $24.90 \mathrm{mg} \mathrm{kg}^{-1}$ \\
Soluble $\mathrm{Na}^{+}$ & $30.00 \mathrm{mg} \mathrm{kg}^{-1}$ \\
Soluble S & $4.40 \mathrm{mg} \mathrm{kg}^{-1}$ \\
Cation exchange capacity & $2.40 \mathrm{mg} \mathrm{kg}^{-1}$ \\
Bulk density & $1.50 \mathrm{~g} \mathrm{~cm}^{-3}$ \\
Infiltration rate (intake rate) & $5.00 \mathrm{~cm} \mathrm{sec}^{-1}$ \\
Saturated hydraulic conductivity & $0.007 \mathrm{~cm} \mathrm{sec}^{-1}$ \\
Field capacity (pF 1.8) & $6 \%$ \\
Permanent wilting point (pF 4.2) & $2 \%$ \\
Texture & Sand (90.68\% sand, \\
\hline
\end{tabular}

Barley is one of the important cereal crops grown in a variety of soils, waters and climatic conditions in various parts of the world and classified as a salt-tolerant crop (Shannon, 1984). The studies on the utilization and management of marginal waters on barley crop are scanty. The present study was aimed to evaluate the effects of saline irrigation water and leaching fraction on barley growth and salt accumulation in soil. More specifically the aim was to investigate the minimum leaching fraction for barley that is effective to minimize the adverse effects of different categories of saline groundwater.

\section{Materials and Methods}

In an open field at the Agriculture and Livestock Research Center, Rumais, Oman ( $\left.21^{\circ} 0^{\prime} 0^{\prime \prime} \mathrm{N} / 57^{\circ} 0^{\prime} 0^{\prime \prime}\right)$, a lighttextured soil was selected for this experiment and the relevant properties are shown in Table 1 . The soil was leveled and plots $(1.5 * 3 \mathrm{~m})$ were prepared for sowing barley (Hordium vulgare L.) (Fig. 1). Soil samples were collected before sowing of the crop and analyzed for $\mathrm{EC}_{\mathrm{e}}$, $\mathrm{pH}$ and some soluble cations. The irrigation water was also analyzed for EC, $\mathrm{pH}$ and some cations (Table TT2). The required levels of EC of irrigation water $\left(\mathrm{EC}_{\mathrm{iw}}=3,6 \&\right.$ $9 \mathrm{dS} \mathrm{m}^{-1}$ ) were prepared through mixing of fresh and saline waters in appropriate ratios. A two meter wide buffer plot was left fallow in between treatment plots of barley to protect and keep separate the effect of different irrigation regimes. Measured irrigation was applied as $\mathrm{ET}_{\mathrm{c}}+\mathrm{LF}$. Irrigation category was kept in the main plots while LF was provided in sub-plots. The drip system of irrigation was installed, and the crop water requirement was calculated by using an evaporation pan (class A). A uniform dose of fertilizer containing $180 \mathrm{~kg} \mathrm{ha}^{-1}$ nitrogen $(\mathrm{N}), 45 \mathrm{~kg} \mathrm{ha}^{-1}$ phosphorus (P), and $80 \mathrm{~kg} \mathrm{ha}^{-1}$ potassium (K) was applied to all plots. The crop was harvested at maturity and the physicochemical properties of the soil and plant were analyzed. This experiment continued on the same site for two years (2008 \& 2009). Necessary preventive measures were taken to protect plants from pests, diseases and birds during growth. Data on plant height, number of tillers, leaf length and width, green and dry fodder yield of crops was measured. More than 72 soil samples were taken and on

Estimation of leaching requirements to grow barley with saline water

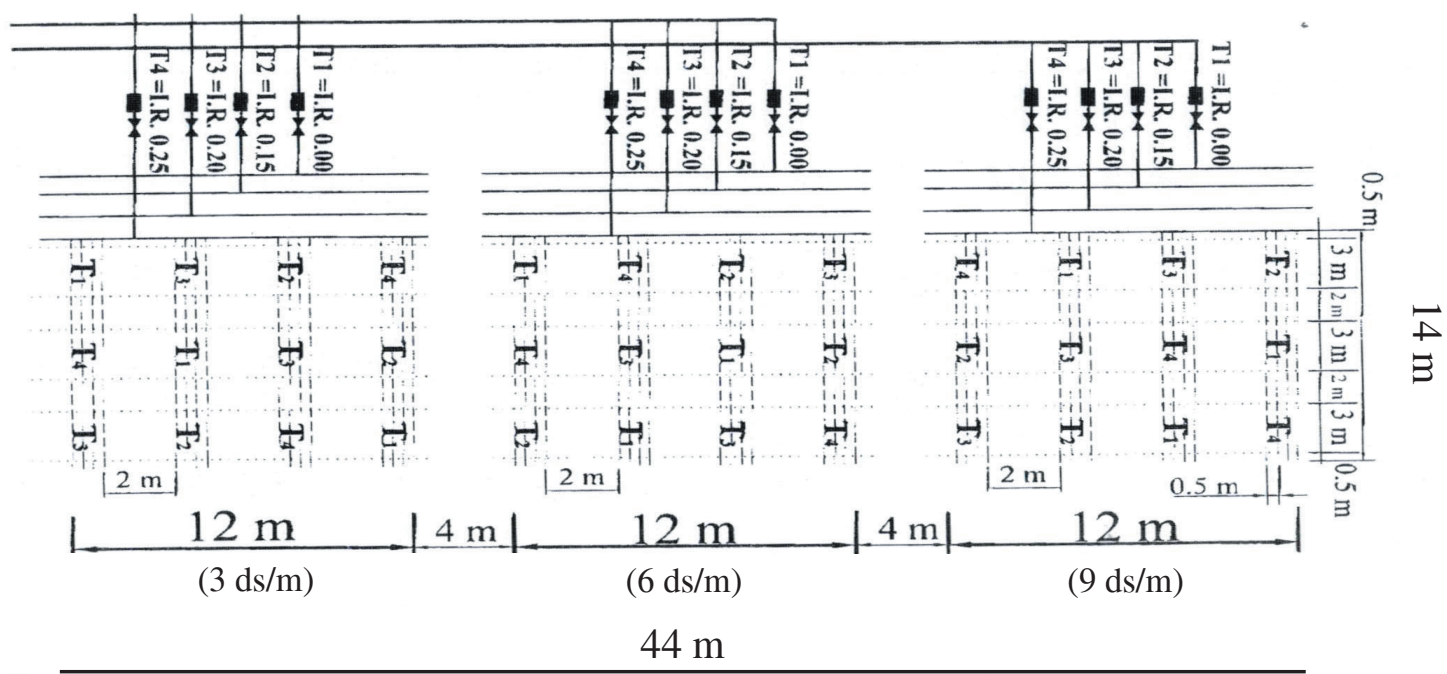

Figure 1. Diagram showing plots and subplots of all treatments. 
Table 2. Chemical properties of irrigation water.

\begin{tabular}{lcccccccc}
\hline Water type & $\mathrm{EC}$ & $\mathrm{pH}$ & $\mathrm{Na}^{+}$ & $\mathrm{Ca}^{2+}$ & $\mathrm{Mg}^{2+}$ & $\mathrm{K}^{+}$ & $\mathrm{S}$ & $\mathrm{Fe}$ \\
\hline Salinity level & $\mathrm{dS} \mathrm{m}$ & - & & \multicolumn{5}{c}{$\mathrm{mg} \mathrm{L}^{-1}$} \\
\hline $3 \mathrm{dS} \mathrm{m}^{-1}$ & 2.95 & 6.80 & 358 & 46.5 & 109 & 5.32 & 46.5 & 0.02 \\
$6 \mathrm{dS} \mathrm{m}^{-1}$ & 6.12 & 6.80 & 677 & 103 & 244 & 10.40 & 109 & 0.01 \\
$9 \mathrm{dS} \mathrm{m}^{-1}$ & 9.10 & 6.90 & 965 & 154 & 367 & 15.30 & 156 & 0.01 \\
\hline
\end{tabular}

each occasion a composite soil sample at two depths (0$30,30-60)$ was air-dried and sieved $(<2 \mathrm{~mm})$. Soil texture was determined by the hydrometer method. Soil salinity was measured through electrical conductivity $\left(\mathrm{EC}_{\mathrm{e}}\right)$ of the soil saturated paste using a conductivity meter. The concentrations of ions in the soil, water and plant were determined by atomic absorption and inductive-couple plasma (ICP) machines.

Data were analyzed statistically for analysis of variance (ANOVA) and the means were compared at a probability level of 5\% using Duncan's Multiple Range Test.

The water deficit in plants was calculated by using the formula:

\section{Water deficit in plant $(\%)=[\{(\mathrm{FWc}-\mathrm{DWc}) / \mathrm{FWc}\}-$ \\ $\{$ FWt-DWt $) / F W t\}] * 100$}

where FWc and DWc are fresh and dry weights of the control and FWt and DWt are fresh and dry weights of the treatments.

The stress factor was calculated by using the formula: Stress factor $\left(\mathrm{K}_{\mathrm{s}}\right)=1-\left[(\mathrm{b} / 100 \mathrm{Ky})\left(\mathrm{EC}_{\mathrm{e}}-\right.\right.$

$$
\text { EC threshold)] (mm) }
$$

where $b$ is the percentage reduction in crop yield per $1 \mathrm{dS}$ $\mathrm{m}^{-1}$ which is equal to 5; Ky is the yield response factor equal to 1; and $\mathrm{EC}_{\mathrm{e}}$ is the soil salinity.
The threshold EC value for barley is considered as 8 $\mathrm{dS} \mathrm{m}{ }^{-1}$ (FAO, 1998).

\section{Results and Discussion}

The salt accumulation and distribution in the soil profile was affected by the amount of salts and quantity of irrigation water applied (Fig. 2). Usually, water uptake by plants and evaporation from the soil surface are the major causes of salt accumulation in the root zone, and salt quantities are proportional to the water volume removed by these processes. This finding was also observed by BenHur et al. (2001) and Bresler et al. (1982). Table 3 shows that salt content in the second horizon is significantly different between all treatments, and that was the real cause for producing significant differences in plantgrowth parameters. The second horizon is commonly used to feed the plant, so salt accumulation or nutrient deficit in this horizon will affect plant growth.

Generally, salt accumulation depended on the soil moisture and plant root development. Higher application of water leached down more salts to the deeper horizons as compared to low water fraction. Soil salinity values fluctuated more under higher salinity and the reason behind that could be the proportional amount of salts added and leached by irrigation water. Petersen (1996) reported low soil salinity with increased volume of irrigation water due to salt transportation below the root zone. Shalhevert

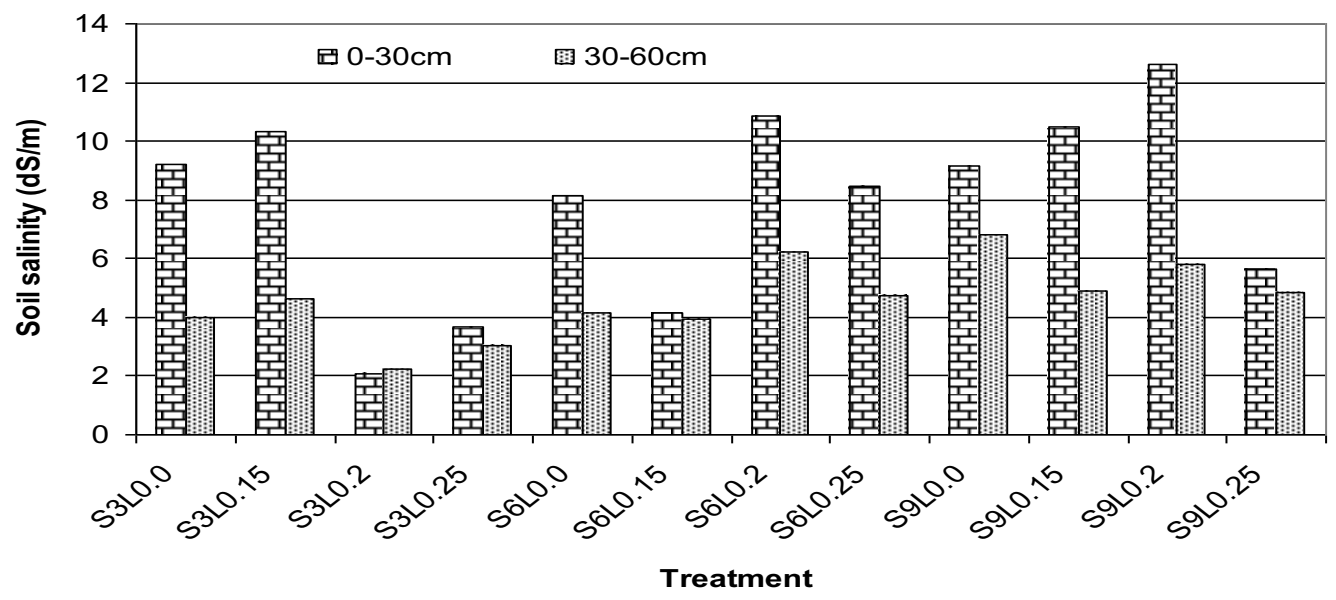

Figure 2. Salt distribution in the soil profile as affected by saline irrigation and leaching treatment (S: saline, L: leaching treatments). 
Table 3. Analysis of variance (ANOVA) for soil and plant parameters.

\begin{tabular}{lccc}
\hline Parameters & $\begin{array}{c}\text { Mean } \\
\text { Square }\end{array}$ & $\begin{array}{c}\mathrm{F} \\
\text { value }\end{array}$ & Significance $^{*}$ \\
\hline Soil EC $_{\mathrm{e}} 0-30 \mathrm{~cm}$ & $4.2 \mathrm{VE7}$ & 1.46 & 0.19 \\
Soil EC $_{\mathrm{e}} 30-60 \mathrm{~cm}$ & 6601154.78 & 3.16 & 0.00 \\
Plant height & 107.28 & 6.17 & 0.00 \\
Leaf length & 18.16 & 5.08 & 0.00 \\
Green yield & 28488.72 & 3.76 & 0.00 \\
Dry yield & 45.51 & 3.25 & 0.00 \\
\hline
\end{tabular}

*Significant at $P<0.05$.

(1994) observed that leaching is the key to the successful use of saline water for irrigation. Whereas, Abu-Awwad (2001) found high salt concentration on the soil surface due to evaporation. Higher application of saline water caused downward flow of salts.

\section{Plant Parameters}

Soil salinity is one of the principal abiotic factors affecting crop yields in the arid and semi-arid irrigated areas. Plant growth was significantly affected by saline irrigation (Table 4). Under less salinity and a high leaching fraction, barley gave substantial biomass yield. Treatment with less salinity gave the higher biomass production as compared to the high salinity. It can be seen from table 4 that plant parameters were negatively affected by an increase in saline irrigation and the reduction in growth can be seen very clearly in figure 3 especially when the plant was irrigated by saline water of $9 \mathrm{dS} \mathrm{m}{ }^{-1}$. However, differences between leaching fractions was not a major factor affecting plant parameters (Table 4). It seems that salt accumulation under the root zone was not very high and so did not affect root water absorption and plant growth. Generally, coarse soil texture supported the leaching treatment and a relatively small amount of water was able to leach salts from the root zone. Moreover, barley is a salt-tolerant crop and a small variation in salt content between each leaching fraction was not enough to reduce plant growth parameters.

Abu-Awwad (2001) reported that saline soils with considerable soluble salts interfered with the growth of crop species. Crop response to salinity usually depends on several factors including plant species, soil texture, waterholding capacity and composition of the salts. During the experiment low concentrations of salts enhanced plant height, tillering and leaf length as compared to higher saline water. Certainly a higher salinity profoundly impaired plant growth parameters. Heakal et al. (1990) noticed that the dry matter yield of plants decreased with increasing salinity of irrigation water. Al-Tahir et al. (1997) found that barley grain and straw yields significantly decreased when irrigated by drainage water (EC: I0.7 16.7 dS m ${ }^{-1}$ ). Pal et al. (1984) concluded that barley could be grown economically with irrigation water up to EC $16 \mathrm{dS} \mathrm{m}$. The greater application of water positively affected plant growth by transferring the toxic level of salts to the lower soil horizons.

Table 4. Plant growth parameters as affected by saline irrigation and leaching treatment.

\begin{tabular}{lccccc}
\hline $\begin{array}{l}\text { Salinity \& } \\
\text { leaching }\end{array}$ & $\begin{array}{c}\text { Plant height } \\
(\mathrm{cm})\end{array}$ & $\begin{array}{c}\text { Leaf length } \\
(\mathrm{cm})\end{array}$ & $\begin{array}{c}\text { Tillers } \\
(\text { No. })\end{array}$ & $\begin{array}{c}\text { Green yield } \\
(\mathrm{g})\end{array}$ & $\begin{array}{c}\text { Dry yield }(200 \mathrm{~g} \\
\mathrm{GY})(\mathrm{g})\end{array}$ \\
\hline S3L0.0 & $40.77 \mathrm{a}$ & $20.07 \mathrm{a}$ & $85.33 \mathrm{a}$ & $411.41 \mathrm{a}$ & $102.05 \mathrm{a}$ \\
S3L0.15 & $44.47 \mathrm{a}$ & $21.40 \mathrm{a}$ & $113.67 \mathrm{~b}$ & $570.85 \mathrm{~b}$ & $105.77 \mathrm{a}$ \\
S3L0.2 & $44.33 \mathrm{a}$ & $20.87 \mathrm{a}$ & $91.00 \mathrm{~b}$ & $441.10 \mathrm{~b}$ & $102.83 \mathrm{a}$ \\
S3L0.25 & $47.27 \mathrm{a}$ & $24.43 \mathrm{~b}$ & $93.67 \mathrm{~b}$ & $491.19 \mathrm{~b}$ & $102.07 \mathrm{a}$ \\
Average & 44.21 & 21.69 & 95.918 & 478.64 & 103.18 \\
S6L0.0 & $43.43 \mathrm{~b}$ & $19.20 \mathrm{c}$ & $96.33 \mathrm{c}$ & $329.15 \mathrm{c}$ & $97.13 \mathrm{c}$ \\
S6L0.15 & $37.37 \mathrm{c}$ & $20.83 \mathrm{c}$ & $79.67 \mathrm{c}$ & $317.40 \mathrm{c}$ & $94.50 \mathrm{c}$ \\
S6L0.2 & $41.17 \mathrm{~b}$ & $21.40 \mathrm{c}$ & $82.00 \mathrm{c}$ & $381.49 \mathrm{c}$ & $101.61 \mathrm{~b}$ \\
S6L0.25 & $39.80 \mathrm{~b}$ & $19.40 \mathrm{c}$ & $85.67 \mathrm{c}$ & $473.50 \mathrm{~d}$ & $104.37 \mathrm{~b}$ \\
Average & 40.44 & 20.21 & 85.92 & 375.39 & 98.40 \\
S9L0.0 & $37.33 \mathrm{~d}$ & $19.80 \mathrm{~d}$ & $106.67 \mathrm{~d}$ & $323.72 \mathrm{e}$ & $99.42 \mathrm{~d}$ \\
S9L0.15 & $30.37 \mathrm{e}$ & $16.20 \mathrm{e}$ & $98.33 \mathrm{~d}$ & $363.03 \mathrm{e}$ & $101.84 \mathrm{~d}$ \\
S9L0.2 & $34.63 \mathrm{~d}$ & $17.63 \mathrm{~d}$ & $78.67 \mathrm{e}$ & $295.94 \mathrm{e}$ & $99.49 \mathrm{~d}$ \\
S9L0.25 & $32.40 \mathrm{~d}$ & $18.03 \mathrm{~d}$ & $102.33 \mathrm{~d}$ & $338.817 \mathrm{e}$ & $94.49 \mathrm{e}$ \\
\hline Average & 33.68 & 17.92 & 96.50 & 330.38 & 98.81 \\
\hline
\end{tabular}

*Means in the column with same letter indicate no difference at Duncan's Multiple Range Test at $P<0.05$. 


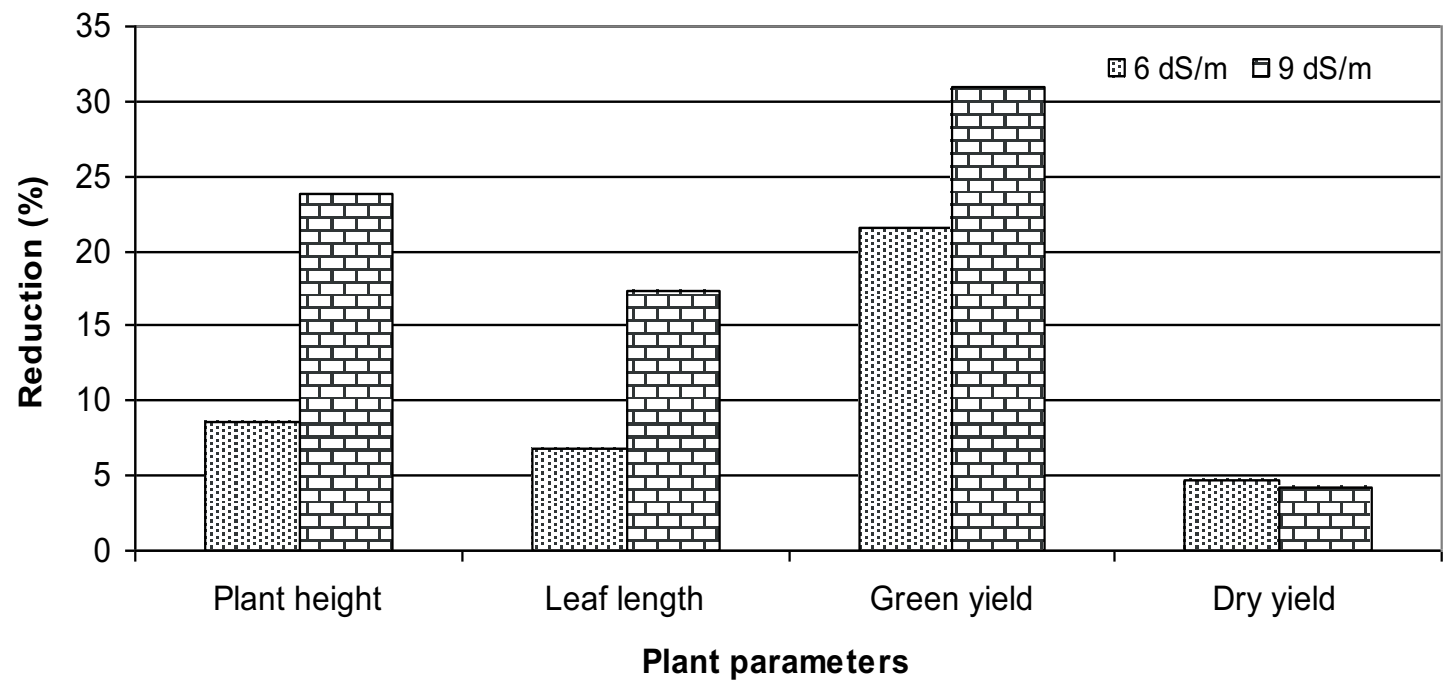

Figure 3. Reduction in plant parameters as affected by salinity treatments.

Saline irrigation water also contains some plantessential elements that are beneficial for plant growth (Table 3). However, those salts if present in high concentration, usually affect negatively plant growth parameters (Fig. 4). The use of saline water for barley irrigation is only possible if the leaching of excess salt from the root zone is implemented. It can be seen from figure 4 that the concentration of most cations in the plant tissue are not very high and they are within the acceptable range that was published in other studies such as Heakal et al. (1990). The higher increase in some cations like phosphorus is due to the application of inorganic fertilizer which contains the essential elements needed for plant growth.

Generally, soil salinity affects plants growth by producing an ionic imbalance or water deficit state in the expanded leaves. Shani and Dudley (2001) related the yield loss to reduced photosynthesis, high energy and carbohydrate expenses in osmoregulation, and interference with cell functions in saline conditions. Heakal et al. (1990) reported that the dry matter yield of plant shoots decreased with the increasing salinity of water. Koszanski and Karczmarczyk (1985) observed that diluted or undiluted seawater reduced plant height, grain and straw yield of barley and oats. In all cases, using highly saline water for irrigation is one of the challenges in saline agriculture.

Table 4 shows that the best growth was with the lowest salinity treatment $\left(3 \mathrm{dS} \mathrm{m} \mathrm{m}^{-1}\right)$. However, comparing the growth of other treatments with lowest one, it can be seen from figure 5 that plant grown under treatment of $9 \mathrm{dS} \mathrm{m} \mathrm{m}^{-1}$ was facing a water deficit problem followed by treatment of $6 \mathrm{dS} \mathrm{m}^{-1}$. It seems that the plants tried to grow

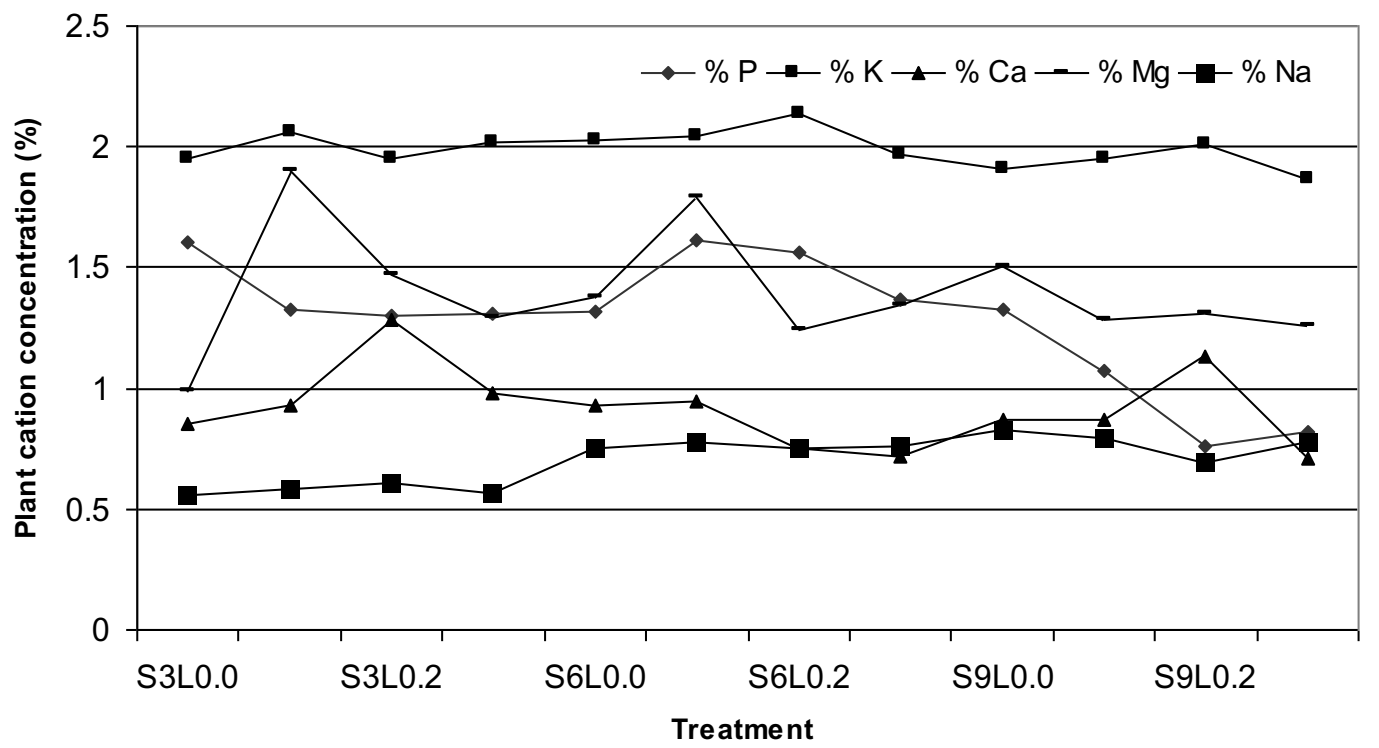

Figure 4. Concentration of some plant cations as affected by saline irrigation and leaching treatment. 


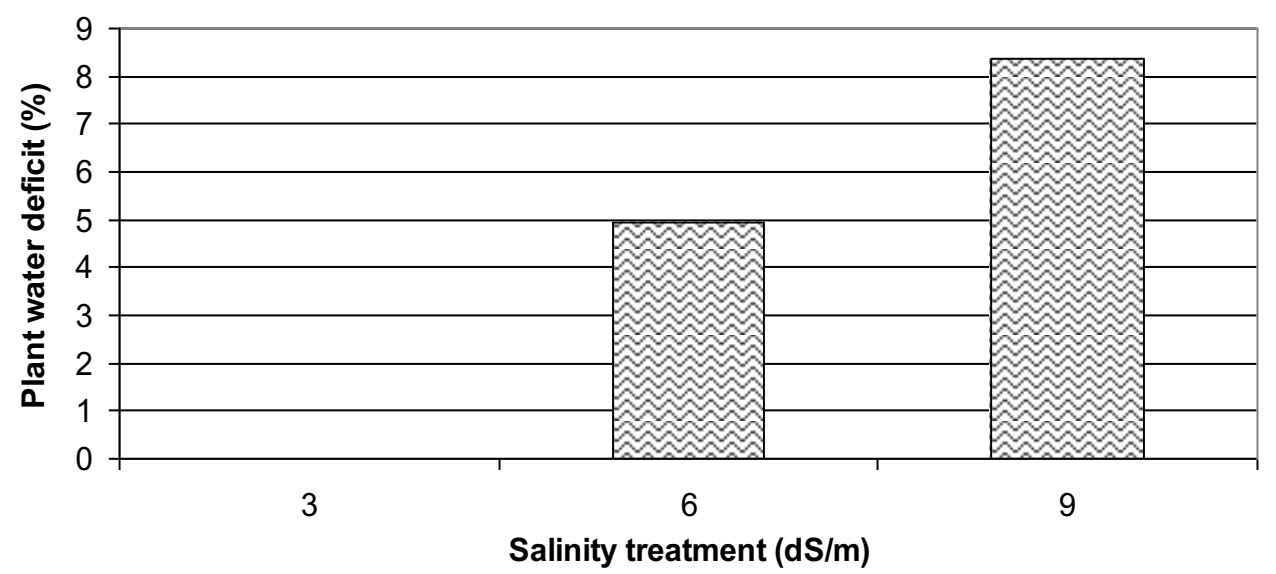

Figure 5. Water deficit between salinity treatments.

and survive under all salinity treatments but the increase in soil salinity was the main barrier for the plant to absorb the required water for growth and that led to osmotic and ion effect problems. The water deficit conditions under high salinity treatments could be directly attributed to the impaired water flow from soil to plant. Yeo (1999) reported that root selectivity and transpirational water flow provide the net uptake of salts whereas the salt concentration develops with the growth rate. The greater mass flow of solution through the soil-root interface or higher magnitude of evapotranspiration would increase the salt transport in plants. Thus, there is a potential risk of higher salt damage in a hot climate.

Within each salinity treatment, there was also a leaching-effect difference. Plants which had no extra water for leaching were facing a water deficit problem (Fig. 6). It was found that a leaching treatment of 0.15 was the best in terms of giving the best growth, so the deficit below that, could be due to a shortage in plant water requirements, and above that, could be due to extra salts added by saline irrigation.

Ghulam et al. (1997) obtained a reasonable barley yield with irrigation water $\left(\mathrm{EC}_{\mathrm{w}}\right)$ up to $9.3 \mathrm{dS} \mathrm{m} \mathrm{m}^{-1}$ under $15 \%$ excess water as a leaching requirement. Thus, the conjunctive use of irrigation water (EC 6.8 9.9 dS m $\mathrm{m}^{-1}$ ) produced higher vegetative growth followed by higher grain and straw yields.

Stress factor $\left(\mathrm{K}_{\mathrm{s}}\right)$ is an additional parameter to determine crop evapo-transpiration. It is an indicator of unusual plants stress such as salinity, deficit water, disease or nutrient imbalance (FAO, 1998). It implies when its value decreases by less than 1 and smaller $\mathrm{K}_{\mathrm{s}}$ value means higher stress. The stress coefficient was not high and in the most treatments, the plant was growing normally (Fig. 7). This happened due to the high salinity threshold value of barley and the effectiveness of sandy soil to leach salts. Plots irrigated with low salinity water produced more biomass which did not decrease $\mathrm{K}_{\mathrm{s}}$ values. The lower $\mathrm{K}_{\mathrm{s}}$

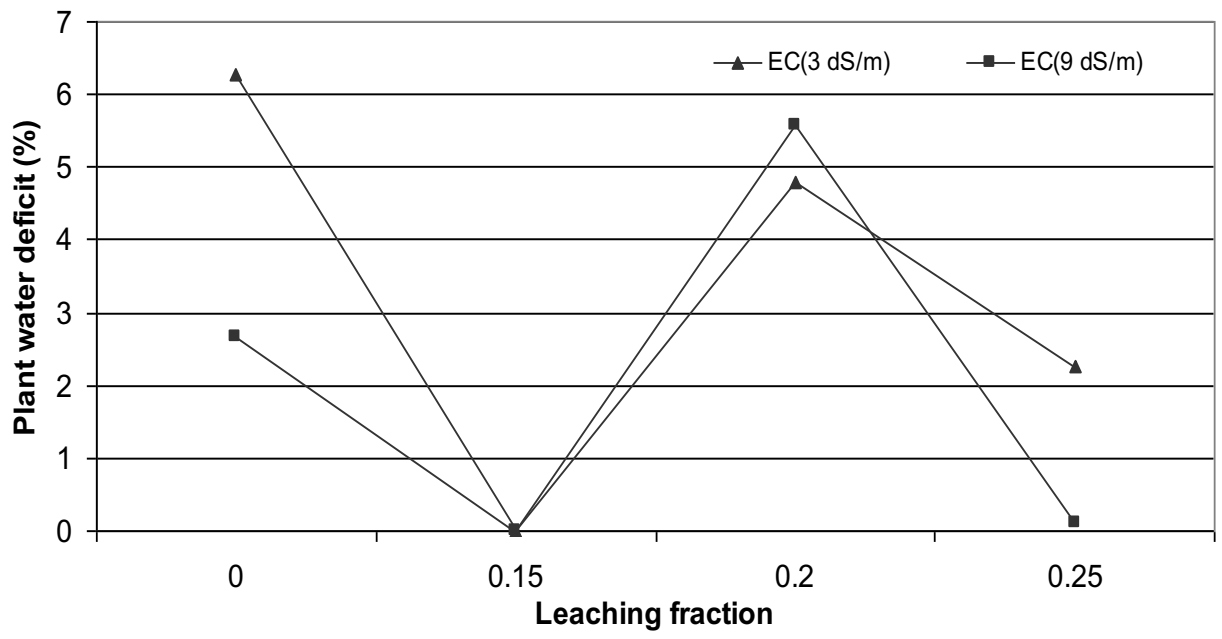

Figure 6. Water deficit between leaching treatments of 3 and $9 \mathrm{dS} \mathrm{m}^{-1}$. 


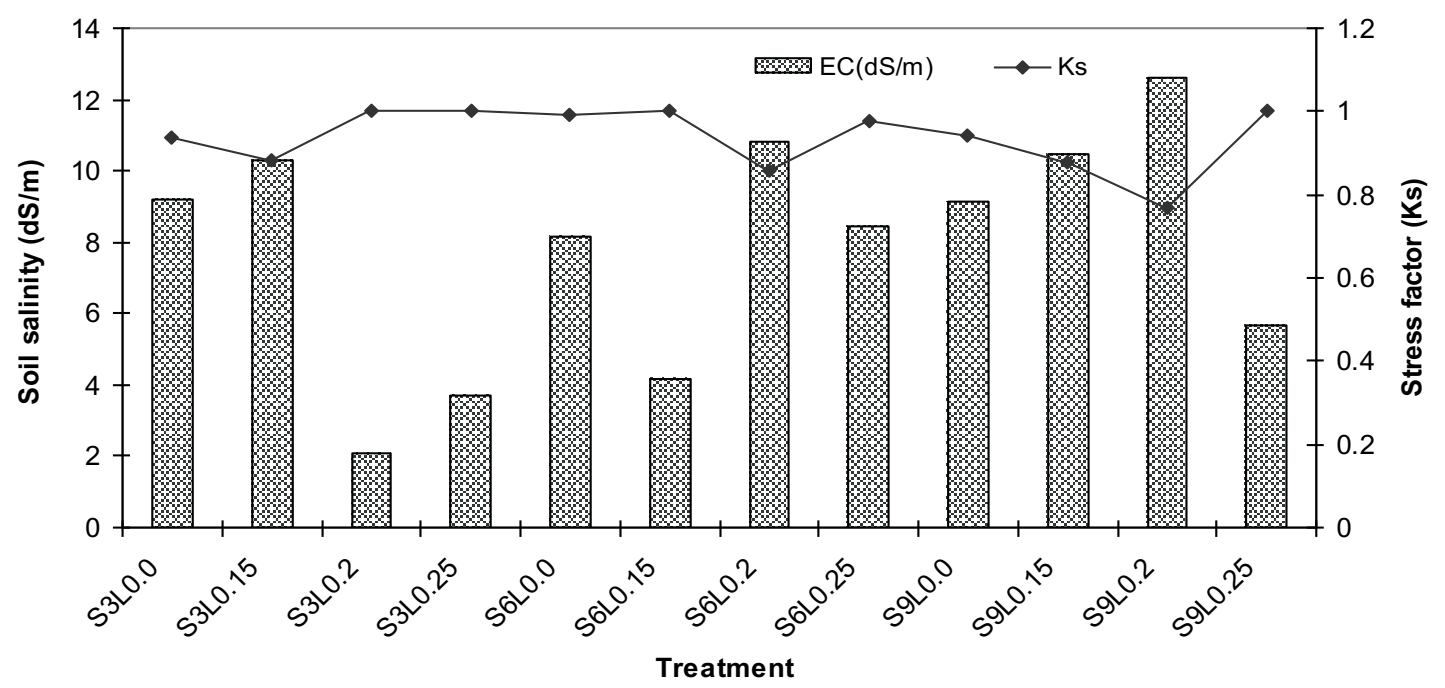

Figure 7. Plant stress factor as affected by saline irrigation and leaching treatment.

values indicated a higher accumulation of salts in the soil under the accelerated evapotranspiration due to growth conditions.

In general the increment in water salinity negatively impacted the value of stress factor and plant growth. The type of soil and salt storage can affect the value of many crop factors, depending on the plant type and growth conditions. It has been reported that soil salinity, land fertility, soil management, fertilizers, soil physical condition, diseases and pests affect crop development and evapo-transpiration (FAO, 1998).

\section{Conclusions}

Our study proves that salinity of irrigation waters along with the given leaching fraction affected the salts accumulation and barley biomass production. Low water salinity with a medium leaching fraction produced substantially higher plant biomass. Under low salinity, plants showed no stress and less water deficit as compared to high salinity. The salinity of post-harvest soil had an inverse relationship with a leaching fraction. Salts were highly accumulated in the top horizons and significantly lower in the lower horizons. The salinity of soil varied with the soil profile, with the maximum salt concentration within transitional horizon of $0 \sim 30 \mathrm{~cm}$. The physical parameters of sandy soil enhanced leaching and decreased the stress factor. There is a need to control the salinity of soils through sustainable use of saline water. These results confirmed that saline water could have greater agricultural potential when used with a rational fraction of leaching.

This experiment indicated that when saline water is used for irrigation due attention should be given to minimize root-zone salinity. However, good management of soil and water could be a viable option for sustainable agriculture in salt affected soils. There is further need to evaluate the effect of poor water quality on different crops in arid and semi arid field conditions.

\section{References}

Abu-Awwad, A.M. 2001. Influence of different water quantities and qualities on limon trees and soil salts distribution at the Jordan Valley. Agricultural Water Management 52:53-71.

Al-Tahir, O.A., Y.A Al-Nabulsi, and A.M. Helalia. 1997. Effects of water quality and frequency of irrigation on growth and yield of barley (Hordeum vulgare L.). Agricultural Water Management 34:17-24.

Ben-Hur, M., F.H. Li, I. Ravina, and G. Shalit. 2001. Water and salt distribution in a field irrigated with marginal water under high water table conditions. Soil Science Society of America Journal 65:191-198.

Bresler, E., B.L. McNeal, and D.L. Carter. 1982. Saline and Sodic Soils: Principles-Dynamics-Modeling. Berlin: Springer-Verlag, 236pp.

Chartzoulakis, K.S., N.V. Paranychianakis, and A.N. Angelakis. 2001. Water resources management in the island of Crete, Greece with emphasis on the agricultural use. Water Policy 3:193-205.

FAO. 1998. Crop evapo-transpiration. FAO Irrigation and Drainage Papers No. 56. Rome.

Ghulam, H., A.A. Al-Jaloud, S.A. Al-Shammary, S. Karimulla, and S.O. Al-Asawad. 1997. Effect of saline irrigation on germination and growth parameters of barley (Hordeum vulgare L.). Agricultural Water Management 34:125-135.

Heakal, M.S., A.S. Modaihsh, A.S. Mashhady, and A.I. Metwally. 1990. Combined effects of leaching fraction salinity and potassium content of waters on growth and water use efficiency of wheat and barley. Plant and Soil 125:177-184. 
Koszanski, Z. and S. Karczmarczyk. 1985. Use of saline water for irrigation of spring barley and oats. Zeszyty-Naukowi-Akademii-Rolniczej-w-Szczecinie, Rolnictwo 36:95-105.

NATO. 1994. Sustainability of irrigated agriculture, part five: water quality management, Proceedings of the NATO Advanced Research Workshop on Sustainability, Vimieo, Lisbon, Portugal.

Oron, G., Y. DeMalach, L. Gillerman, I. David, and S. Lurie. 2002. Effect of water salinity and irrigation technology on yield and quality of pears. Biosystems Engineering 81:237-247.

Pal, B., S. Singh, and H. Singh. 1984. Barley yield under saline water irrigation. Plant and Soil 81:221-228.

Petersen, F.H. 1996. Water Testing and Interpretation. In: Water, Media, and Nutrition for Greenhouse Crops, D.W. Reed (Editor), 31-49. Batavia: Ball.
Shalhevert, J. 1994. Using water of marginal quality for crop production: major issues. Agricultural Water Management 25:233-269.

Shani, U. and L.M. Dudley. 2001. Field studies of crop response to water and salt stress. Soil Science Society of America Journal 65:1522-1528.

Shannon, M.C. 1984. Breeding, selection and the genetics of salt tolerance. In: Salinity Tolerance in Plants, R.C. Staples and A.H. Toenniessen (Editors), 231-254. John Wiley, New York.

Yeo, A. 1999. Prediction the interaction between the effects of salinity and climate change on crop plants. Scientia Horticulturae 78:159-174.

Received: October 24, 2010

Accepted: April 3, 2012 